\title{
The Role of Dynamic Capabilities Based on Digital Literacy on The Performance of Marketing Innovations for Micro, Small and Medium Enterprises
}

\author{
Rendra WIRAWAN $^{1^{*}}$, Isti FADAH ${ }^{2}$, Ika Barokah SURYANINGSIH ${ }^{3}$, Deasy WULANDARI $^{4}$ \\ 1,2,3,4 Universitas Jember, Indonesia \\ Email: rendrahipmijember@gmail.com¹ ${ }^{1}$,barokah.feb@unej.ac.id ${ }^{3}$ \\ ${ }^{*}$ Corresponding Author
}

\author{
Received: 01.07.2021 \\ Accepted: 06.09.2021 Published: 20.10.2021 \\ DOI: 10.47750/QAS/22.184.22
}

\begin{abstract}
This study aims to determine the effect of environmental strategy on dynamic capabilities based on digital literacy and the performance of marketing innovations for micro, small and medium enterprises. Digital literacy-based dynamic capabilities consist of two important components, namely marketing competencies and research and development competencies. The nature of this research is explanatory where the number of research samples is micro, small and medium enterprises that have used information technology with a total number of respondents as many as 200 micro, small and medium enterprises which are divided proportionally to seven regions in Indonesia with the sampling method using accidental sampling method. The data analysis technique used SEM analysis with the help of AMOS software. The results showed that environmental strategy had no significant effect on marketing competence. Environmental strategy has a significant effect on the direction of a positive relationship to research and development competencies and has a significant effect on the direction of a positive relationship on the marketing innovation performance of micro, small and medium enterprises. Marketing competence and research and development competence have a significant effect with a positive direction of relationship to the marketing innovation performance of micro, small and medium enterprises. Research and development competence has a significant effect on the direction of a positive relationship to the marketing performance of micro, small and medium enterprises.
\end{abstract}

Keywords: environmental strategy, marketing competence, research and development competence, marketing innovation performance, micro, small and medium enterprises

\section{Introduction}

The influence of globalization flows is basically difficult to prevent and requires attention to the various possible challenges, threats, obstacles and disturbances that exist as well as policies and strategies to overcome them. It is hoped that Indonesia, which is a developing country, will become more aware of the importance of being aware of the various possible challenges of globalization. As a democratic country, Indonesia has entered the global vortex of globalization, which is an era full of challenges and opportunities (Yuniarto, 2015).

Globalization accompanied by technological advances has changed the pattern of human life. Technological progress, which is reflected in the increasing number of digitalisations, shows that technology has integrated all lines of life, from the social, economic, political, cultural and so on. Digitalization has also had a positive impact on the acceleration of various performances both from government performance and economic activity. Performance systems that are integrated by the presence of digital technology tend to show transparent, effective and efficient results. Digital also provides an advantage because it can provide information and data more quickly and accurately, where data and information can be a model for formulating an institutional and institutional strategy (Nasution, 2017).
Technological progress is something that cannot be avoided in this life, because technological progress will run in accordance with scientific advances. Technological progress is influenced by the industrial revolution 4.0 which integrates the physical, digital, and biological worlds where there are fundamental changes in the way human life works. The impact of the industrial revolution 4.0 is also developing for the online trade and transportation transaction process. This shows the impact of the 4.0 industrial revolution on human knowledge which can create an innovation (Hamdan, 2018).

One of the sectors that has had the impact of technological advances in Indonesia is the micro, small and medium enterprises sector. The current fast digital era can encourage entrepreneurship to open entrepreneurship easily with the various benefits and conveniences that are obtained, to grow the number of MSME players who surf in cyberspace, the Ministry of UMKM Cooperatives and the Ministry of Communication and Informatics together with e-commerce players initiated a program entitled 8 Million MSMEs Go Online. Through this collaboration, the government also hopes to accelerate the transformation of MSMEs in Indonesia to digital (Salsabila, 2019).

Based on research conducted by Amri (2020), it is stated that one of the businesses that was greatly affected by the Covid-19 pandemic situation in Indonesia was MSMEs. Cooperative managers feel that sales have fallen, lack of capital, and 
distribution constraints. Meanwhile, the MSME sector which was shaken during the Covid-19 pandemic apart from food and beverages, was also the creative industry and agriculture. According to Habibi (2020), new normal can be interpreted as a condition and / or social habits of society or individual behavior that appears after Covid-19 is over. Like the new normal, the old normal is the social condition of the community before the Covid19 pandemic (Muhyiddin, 2020).

An effective and efficient strategy is important to become an integral part of the development of the MSME sector. Along with technological developments, an effective strategy in encouraging developments both in terms of competitiveness and expansion of market share in the MSME sector is by revolutionizing the marketing system. Based on research conducted by Mokhtar (2015) which emphasizes the discussion of digital marketing analysis in the MSME sector by emphasizing marketing strategies in conventional and digital forms (digital marketplace) for the development of home industry business units. Ismail's research results (2020) explain that the existence of Covid-19 will produce three important patterns, namely delocalization, digital challenges, and changes in attitudes after post-Covid-19. The occurrence of the Covid-19 pandemic has shaken the MSME sector, both small, micro, and medium. Not many MSMEs have succeeded in making adaptations or adjustments at this time of the year. One of the ways of adaptation made by several MSMEs is by changing the marketing system from offline to online (Rosita, 2020).

Based on the results of Pratiwi's research (2020) the impact of the Covid-19 economic slowdown is an obstacle for MSMEs to continue to exist in their fields. The existence of socia distancing policies, Large-Scale Social Restrictions (PSBB), and Restrictions on Community Activities (PKM) will hinder the movement or mobilization of community behavior in meeting the needs and availability of raw materials. The most significant impact of the Covid-19 pandemic on MSMEs is the reduction in sales value which causes the value of capital to also decline. So in this case the government must examine what efforts are faced by MSMEs and solutions that can help restore the condition of MSMEs. Based on the results of the study by Sugiri (2020) that the efforts that have been made by the government in Indonesia are providing social assistance, tax incentives, relaxation and credit restructuring for MSMEs, expansion of working capital financing, provision of product support, MSME labor market intervention through training with methods E-learning, as well as the application of health protocols in the business world.

Some of the research results that have differences so that researchers can fill the research gap are research conducted by Brammer et al., (2012) on the effect of environmental strategy on marketing competence. This research is also supported by research conducted by Arend (2014) and Ko \& Liu (2016). In addition, the influence of research and development competencies has an effect on marketing competence in accordance with research conducted by Erlanitasari et al., (2020); Faccin et al., (2019); Suliswanto \& Rofik (2019); Tiago \& Veríssimo (2014). However, research conducted by Schilke et al., (2018) has the results of research and development competencies that have no effect on marketing competence.

Research conducted by Day \& Schoemaker (2016); Hermawati \& Gunawan (2020); Mohamud \& Sarpong (2016) have the results of literacy or learning that have an effect on innovation. However, Roach et al., (2018) have the opposite result. The influence of marketing competence affects innovation performance. This is in accordance with research conducted by Bekoglu \& Onaylı (2016); Constantinides (2014); Kosasi et al., (2018). However, these results are inversely proportional to research by Röder (2017) which states that marketing competence has no effect on innovation performance.

Dynamic capability is an effort or strength of MSMEs in adapting to existing resources in producing fast and on target values. During this pandemic, dynamic capabilities are needed in an effort to accelerate MSMEs to get up and make adjustments. Indicators and capabilities of the resources of an MSME will create superior resources, high market prospects, and have a good impact on the environment. Based on the results of research from Irawan (2020), the identification of the sweet capabilities of MSMEs is: wide access to the market to remote areas, business products launched bring benefits to consumers, and the characteristics of products launched are very distinctive and not easily imitated by business people. another. The new normal condition as a result of adjustments to this pandemic condition also has an unstable economic impact so that the activities of micro, small and medium enterprises are also unstable. Some of the activities carried out by MSMEs are slightly hampered, such as the availability of raw materials which is starting to become difficult because trading activities are starting to be restricted, consumer behavior has also changed, and limited marketing if carried out conventionally. This dynamic capability based on digital literacy on the performance of marketing innovation and research and development competencies of MSMEs is something new and is based on existing phenomena and is supported by several previous studies that did not exist before.

\section{Literature Review}

\subsection{Dynamic Capability Theory, Digital Literacy, Environmental Strategy and Innovation Performance}

Dynamic capability is a model that has been successfully developed by Teece \& Pisano (1994), a theory that examines the potential and ability of a group or organization to create, reform or reshape and still exist in dynamic competition. Based on Teece \& Pisano (1994) in developing a model it is necessary to examine how competitive advantages are obtained and as much as possible to be maintained. Dynamic capability theory also examines how the process of knowledge management relationships with dynamic capabilities that have an impact on organizational performance. What needs to be learned is how organizational membership has an open mindset and the ability to collaborate between disciplines can be realized (Kristinawati \& Tjakraatmadja, 2018).

Dynamic capabilities are the ability to shape, reshape, configure, and reconfigure company capabilities so that they can respond well to environmental changes. There is a significant relationship between dynamic capabilities and competitive advantage. In a relatively stable environmental condition, the company is sufficient to make adjustments and improvements to its capabilities (incremental dynamic capabilities). The capability adjustment process is carried out through continuous improvement activities. In a dynamic business environment, renewing dynamic capabilities are carried out. In this situation the company is not only making adjustments but also making changes to its capabilities (Parida et al., 2016).

According to Khalil \& Belitski (2020) in his research, he explains about dynamic capabilities and empirically examines the role played by digital dynamic capabilities in decisive performance for SMEs in Europe. Some of the frameworks and references in this research are information and technology frameworks with three processes, namely mechanism, structure, and relational. These three processes are in information technology governance concerning strategic, managerial, and operational issues. This research is similar to the research conducted by Essid \& Berland (2018), the study states that based on the dynamic capability approach to understand how organizational capabilities are in managing technology adoption 
by eight large companies in France. The approach used is dynamic operational capabilities and environmental management control issues.

To be able to have dynamic capability, a company needs to have three capabilities, namely adaptive capability, absorptive capability, and innovative capability. Adaptive capability is the ability to identify and capitalize on opportunities that arise from the market. Adaptive capability is measured by the ability to respond to opportunities, monitor markets, customers and competitors, and allocate resources for marketing activities. Absorptive capability is defined as the ability to evaluate and use knowledge from outside the organization. Absorptive capability is measured from the intensity of research and development activities. The innovative capability is defined as the ability to develop new products or markets. Innovative capability is measured by the number of product or service innovations, process innovation, and new problem solutions (Tseng \& Lee, 2014).

Dynamic capabilities are generally implemented through four stages. First, identification and assessment of environmental changes that may lead to changes in industrial management. Second, conduct an assessment to explore the suitability of company resources and capabilities. Third, make adjustments or renewals, or replace resources and capabilities so that they can become a source of competitive advantage for the company. Fourth, utilize renewed resources and capabilities to formulate and implement strategies in order to gain new competitive advantages (Gonzalez \& Melo, 2019).

Marketing competence which states that managerial capabilities will be superior when those capabilities are in the context of a team rather than individuals, because the expertise of the team has the various kinds of technical and human skills needed to achieve superiority. Resource-Based View (RBV) theory assumes that a company can be conceptualized as a group of resources that are heterogeneously distributed throughout the company. To contribute and contribute to the development of the next strategic management RBV (Barney, 1991). A business transaction between two or more parties will occur if each of them trusts each other. Therefore, trust becomes the foundation in business. This trust cannot just be recognized by other parties / business partners, but must be built from scratch and can be proven. Trust is a central element for the success of a relationship (Hunt, 1997). In addition, Morgan \& Hunt (1999) stated that loyalty is a form of commitment formed by trust as the main factor and conceptualizes trust when a group believes that an exchange partner has reliability and integrity.

Marketing can also be interpreted as an overall system of business activities aimed at planning, pricing, promoting, and distributing goods and services that satisfy the needs of both existing and potential buyers (Borchardt et al., 2020). According to Ko \& Liu (2016), several things can be considered in determining marketing competence. Marketing competence refers to the company's ability to create new competencies in exploring new, temporary markets. In addition, ownership of marketing competencies allows companies to develop new competencies to explore fresh markets with the aim of expanding the customer base of a company.

Research on phenomena that are fundamental to education is carried out through basic research, while research on educational practice is carried out through applied research. There is often a gap between the results of basic theoretical research and applied research that is practical in nature. This gap can be bridged by the existence of research and development $(R \& D)$. In the implementation of this $R \& D$, there are several methods that can be used, namely: descriptive, evaluative, and experimental. Descriptive research method, used in preliminary research to collect data about existing conditions. The evaluative research method is used to evaluate the trial process of developing a product. The experimental research method is used to test the efficacy of the products produced (Wang, 2016).

Based on research conducted by Faccin et al., (2019) stated that dynamic capabilities in joint R\&D projects enable them to successfully achieve knowledge creation and discover how they behave throughout the collaborative project life cycle, although this understanding can enhance the knowledge creation process between organizations. Knowledge-based dynamic capabilities for successful innovation outcomes in joint R\&D projects. Competence as a basic characteristic of a person that enables employees to perform superiorly in their work ". Competence is a deep and inherent part of a person's personality with predictable behavior in various situations and job tasks. The prediction of who is performing well and poorly can be measured from the criteria or standards used (Denford, 2013; Han \& \& Li, 2015).

The term "information literacy" was first put forward by Paul Zurkowski, he stated that people who are information literate are people who are trained in the application of resources in their work. Information literacy skills are very important because of the rapid advancement of technology. The dissemination of various information that is correct and polite will make the recipient of the information reason properly so that they are not easily provoked into doing disturbing things. Thus, information literacy is very important to support national resilience (Behrens, 1994). Literacy requires a range of cognitive abilities, knowledge of written and spoken language, knowledge of genres, and cultural knowledge (Manderino \& Castek, 2020). According to AdamTurner et al., (2020), literacy requires complex abilities. The knowledge about genre is knowledge about the types of texts that are applied / used in the discourse community, for example, narrative texts, expositions, descriptions and others.

The development of digital equipment and access to information is certainly a challenge and an opportunity. With relatively high internet usage, stakeholders must consider the best way to deal with hoax news or information, hate speech, and intolerant behavior that can be easily found on social media (Gibson \& Smith, 2018). According to Kozanoglu \& Abedin (2020), the term literacy refers to knowledge and skills in a particular field. Digital media allows for opportunities, such as increasing profits in the e-commerce business, the birth of new jobs based on digital media, and the development of literacy skills without negating print-based text (lkpeze, 2018). When companies have sufficient digital skills, businesses can build relationships with consumers much more intensely. Consumers become more and more and ultimately increase in income (Feerrar, 2019).

Basically, external environmental analysis includes two aspects, namely opportunities and threats (Ajibroto et al., 2018). Three types of uncertainty in the environment: influence, response, and circumstances. Influence uncertainty is the inability to predict the nature of the effect of the future state of the environment on the organization, and response uncertainty is the inability to predict the possible consequences of response choices. State uncertainty refers to the perceived environmental uncertainty (Xu \& Wang, 2019).

Today's business development is full of demands for marketing innovation. The important features of product research and development activities are (1) the success of product innovation activities is not easy to determine from the start - many product innovations fail but only a few have had tremendous success; (2) the results of product innovation activities are also in the form of intangible assets for the company so that these assets only benefit the company; (3) there is not much debt funding available to be used to finance research and development of new products and also to finance the launch of new products to the market (Gupta et al., 2016; 
Qurtubi et al., 2019). The existence of the company's ability to apply organizational learning will provide encouragement for companies to create efforts to utilize all available resources based on the learning carried out. These efforts will have an impact on the easier it is for companies to be able to create and apply an appropriate innovation strategy (Denford, 2013).

\subsection{Hypothesis}

Based on research conducted by Faccin et al., (2019), it shows that collaborative research and development (R\&D) projects use dynamic capabilities based on knowledge of various phases in process development, meaning that the procedures of each organization or company can change as long as the project is still being carried out. Research conducted by Khalil \& Belitski (2020) shows dynamic capabilities and empirically examines the role that digital dynamic capabilities play in decisive performance for SMEs. Based on research conducted by Essid and Berland (2018), it is stated that the use of the dynamic capability approach and its operationalization in environmental management control issues. The study of dynamic capabilities in the field of research information systems reveals that trends show that the investigated domain and its sub-domains that are prominent generally have positive productivity over the past few years (Talafidaryani, 2020).

$\mathrm{H} 1$ : Environmental strategy has a significant effect on marketing competence

$\mathrm{H} 2$ : Environmental strategy has a significant effect on research competence and

H5: Research and development competencies affect marketing competencies

Based on research conducted by Hermawati \& Gunawan (2020), it shows that managers must be eager to adapt their innovations to a changing environment and continue to update predetermined plans. Learning is a continuous process necessary for innovation, requiring the latest support from the knowledge generated through learning. For this reason, learning is required in all dynamic ability processes. According to Nuhu et al., (2019), in his research, he stated to examine the role of organizational dynamic capabilities (strategic flexibility and employee empowerment) in mediating the relationship between management control systems (MCS), in particular interactive and diagnostic approaches to using control, with change and performance. organization. According to research conducted by Han \& \& Li (2015), it is stated that to determine the effect of intellectual capital on the innovative performance of a company, it can be done with a strategic environmental analysis. Based on Denford's (2013) research identifying more than 80 knowledgebased dynamic abilities in the literature review, three common dimensions among the framework were identified and integrated into a typology of eight knowledge-based dynamic abilities to cover the existing literature. The most important point of the framework developed in this study is to determine whether capabilities are more or less strongly related to performance constructs. Based on research conducted by Khan et al., (2020) it shows that the dominant logic (information filters and learning orientation) provides a solid basis for increasing performance innovation in SMEs. To be successful in the SME market it is necessary to invest well in managerial skills. Based on research by Kosasi et al., (2018) states that the success of micro, small and medium enterprises (MSMEs) is determined by capital assets and the ability to adopt social media technology innovations to formulate digital marketing strategies to increase organizational agility.

H3: Environmental strategy has a significant effect on the performance of marketing innovation

$\mathrm{H} 4$ : Digital literacy-based marketing competencies affect the performance of marketing innovation

H6: Research and development competencies affect the performance of marketing innovations

\section{Method of the Study}

This research uses quantitative research. The population in this study were all micro, small and medium enterprises in the Jember Bakorwil area. The sample in this research amounted to 200 respondents using proportional sampling technique by region. The data sources used are primary data sources obtained based on questionnaires and interviews with respondents. The analytical tool used in this study uses a structural equation model.

\section{Results}

The environmental strategy variable consists of three indicators, namely not damaging the environment (TML), reducing environmental impact (MDL) and reducing environmental accidents (MKL). Marketing competency variables consist of six indicators, namely assessing the potential of digital literacy-based markets (MPPD), building digital literacy-based relationships (MHD), preparing digital literacy-based (MDD) distribution, utilizing digital literacy-based advertising (MPD), assessing digital literacy-based competitors. (MKD) and digital-based pricing strategy (SPD). The research and development competency variable consists of four indicators, namely assessing new digital literacy-based technologies (MTD), preparing digital literacy-based activities (MKB), recruiting digital literacy-based experts (MAD) and preparing digital literacy-based production processes (MPSD). Marketing innovation performance variables consist of six indicators, namely product range expansion (PJP), increased sales turnover (POP), increased business profit (PKU), increased brand strength (PKM), product information updates (UIP), increased new consumers (PKB). . The structural model that is built is as follows: 


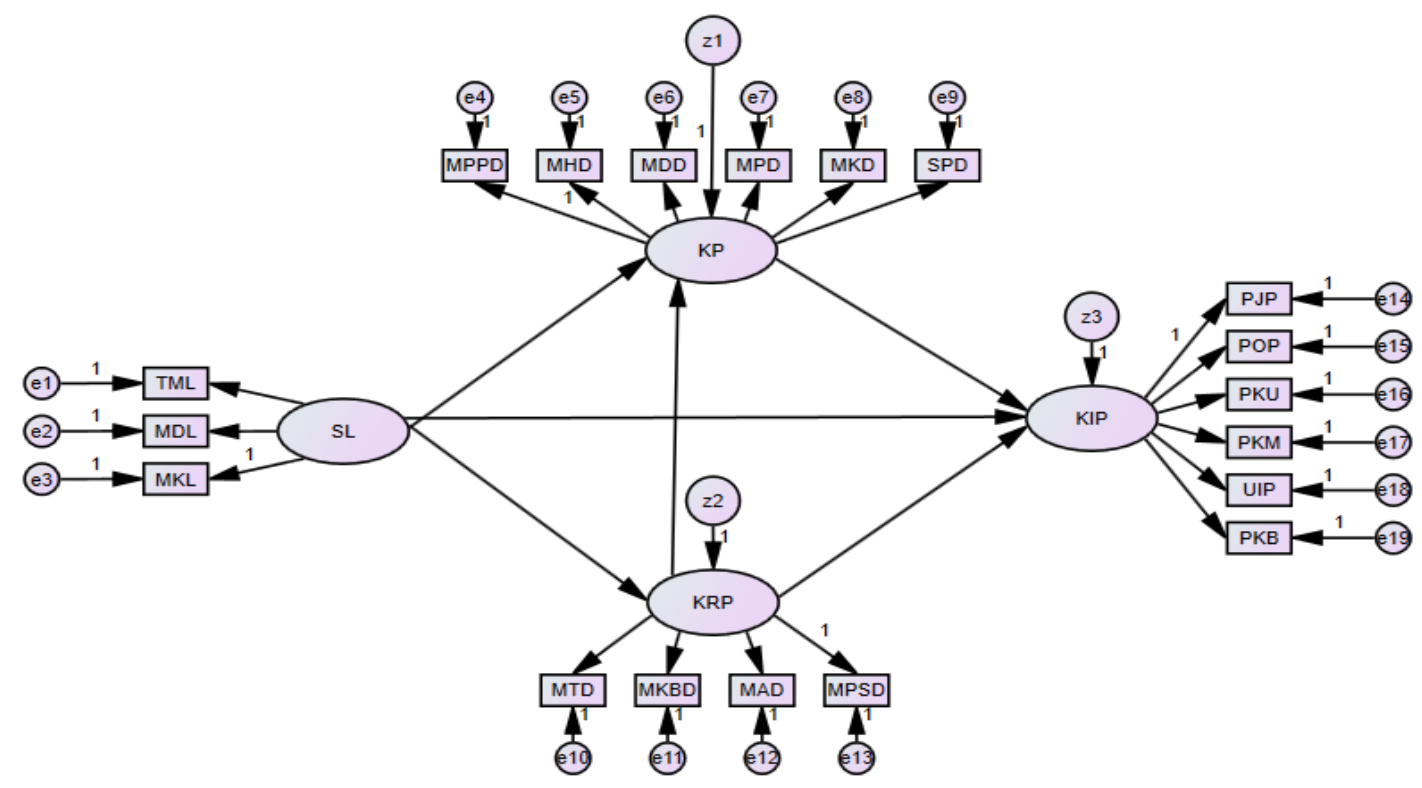

Figure 2: Structural Research Model

Data analysis was carried out to determine the research data that had been obtained in accordance with the concepts that had been prepared. Data analysis for each study varies depending on the method and type of research being carried out. In this study, the data analysis used included: data validity and reliability tests, SEM assumption tests, Goodness of Fit tests and hypothesis testing. The results of data validity and reliability tests according to table 1 indicate that all data on variables and indicators are declared valid because the correlation value of each indicator item is greater than 0.3 and all data on variables and indicators are declared reliable because the Cronbach alpha value of each indicator is greater than 0,6 .

\section{Discussion and Conclusion}

Environmental strategy is a variable whose indicators relate to the relationship between environmental health. Hypothesis test results of the relationship between environmental strategy and marketing competence are not significant. This insignificant influence is influenced by several factors. One of the factors that influence the relationship between environmental strategy and marketing competence is the adaptability of these variables in developing the strategic potential of a company or MSME (David, 2011). Environmental strategies are mostly carried out by organizations or strategic environmental analysis is part of the strategic planning component and is a process to always place the company in a strategic position, so that in its development it will always be in a favorable position (Ajibroto et al., 2018). Marketing can be defined as an overall system of business activities aimed at planning, pricing, promoting, and distributing goods and services that satisfy the needs of both existing and potential buyers (Borchardt et al., 2020). So that digital literacybased marketing competences explore more the market with the aim of exiting, while environmental strategy is more related to the production process and traversing into the company. The results of this study support the research of Larrán Jorge et al., (2015) which shows that environmental strategy has no significant effect on marketing competence and the results of this study do not support the research conducted by Arend (2014); Brammer et al., (2012); Danneels (2012); Ko \& Liu (2016). The use of a digital literacy-based dynamic capability model is still not able to accommodate the achievements in each of the aspects applied to the environmental strategy variables and marketing competencies. Therefore, the use of a digital literacybased dynamic dynamic capability model that has no effect on the relationship of certain variables can be used as a reference in creating an open mindset centered on the cooperation capabilities of the company or industry components or MSMEs in the success of the policy points that are owned in each variable. used (Kristinawati \& Tjakraatmadja, 2018).

Based on the results of data analysis, it was found that environmental strategy had a significant effect on digital literacybased research and development competencies with a positive relationship direction. The results of this study support the research conducted by Arend (2014); Brammer et al., (2012); Danneels (2012); Hamann et al., (2015); Ko \& Liu (2016). Environmental strategies that are more inward-oriented and related to the production process of MSMEs have a relationship with research and development competencies. Research on phenomena that are fundamental to education is carried out through basic research, while research on educational practice is carried out through applied research. There is often a gap between the results of basic theoretical research and applied research that is practical in nature. This gap can be bridged by the existence of research and development (R\&D). In the implementation of. In this R\&D, there are several methods that can be used, namely: descriptive, evaluative, and experimental (Wang, 2016). Dynamic capability in this case refers to two main points, namely the first term from dynamic which means a shift in the environment, strategic plans, and the time needed to accelerate an innovation. Then the next meaning is the power that functions as the key to accelerating both external, internal conditions and the role of resources in environmental change (Teece \& Pisano, 1994). Companies will tend to be motivated to develop research and development (R\&D) competencies, which enable them to build new technological competencies. Ownership of these competencies often enables companies to identify and integrate new green-based technologies for their product development and develop environmentally friendly products to replace discontinued products. Therefore, companies can maintain the scale and scope of their product offerings at the same level that existed before the implementation of their environmental strategy (Ko and Liu, 2016).

marketing innovation performance with a positive relationship direction. The results of this study support the 
results of research conducted by Arend (2014); Ko \& Liu (2016); Suliswanto \& Rofik (2019). Dynamic capability in this case refers to two main points, namely the first term from dynamic which means a shift in the environment, strategic plans, and the time needed to accelerate an innovation. Then the next meaning is the power that functions as the key to accelerating both external, internal conditions and the role of resources in environmental change (Teece \& Pisano, 1994). Dynamic capabilities are generally carried out in four stages, first, identifying and assessing environmental changes that can lead to changes in industrial management, second, conducting an assessment to explore the suitability of company resources and capabilities. Third, make adjustments or renewals, or replace resources and capabilities so that they can become a source of competitive advantage for the company. Fourth, utilize renewed resources and capabilities to formulate and implement strategies in order to gain new competitive advantages (Gonzalez \& Melo, 2019). Technological innovation helps companies to build competitive advantages, more effective services and processes, new businesses, and so on (Rashidirad \& Salimian, 2020). Environmental strategies are mostly carried out by organizations or strategic environmental analysis is part of the strategic planning component and is a process to always place the company in a strategic position, so that in its development it will always be in a position that benefits the company or industry (Ajibroto et al., 2018).

Digital literacy-based research and development competencies have a significant effect on digital literacy-based marketing competencies with a positive relationship direction. The results of this study support the research conducted by Arend (2014); Faccin et al., (2019); Hamann et al., (2015); Tiago \& Veríssimo (2014). Managers must be eager to adapt their innovation to a changing environment and constantly update their predetermined plans. Learning is a continuous process necessary for innovation, requiring the latest support from the knowledge generated through learning. For this reason, learning is required in all dynamic ability processes (Hermawati \& Gunawan, 2020). To be successful in the SME market it is necessary to invest well in managerial skills. Therefore, in a very volatile and uncertain environment, SMEs utilize the resources of a business unit, such as the dominant logic tends to be more innovative and gain a competitive advantage (Khan et al., 2020).

The results show that digital literacy-based marketing competencies have a significant effect with a positive direction of relationship on the performance of MSME marketing innovations. The results of this study support the research conducted by Arend (2014); Brammer et al., (2012); Hamann et al., (2015); Hermawati \& Gunawan (2020). The marketing aspect is a very important aspect of performance for a company. Marketing competence which states that managerial capabilities will be superior when those capabilities are in the context of a team rather than individuals, because the expertise of the team has the various kinds of technical and human expertise needed to achieve superiority. Companies will have difficulty managing these resources and therefore their capabilities will not be optimal. This is clear because with the company's ability to manage all of its resources, the company's performance will increase. Resource-Based View (RBV) theory assumes that a company can be conceptualized as a bundle of resources that are heterogeneously distributed throughout the company. contribute to the development of the next strategic management RBV (Barney, 1991).

The results showed that digital literacy-based research and development competencies had a significant effect on the performance of MSME marketing innovations with a positive direction. The results of this study support the research conducted by Arend (2014); Danneels (2012); Erlanitasari et al., (2020); Jorge et al., (2015); Lee et al., (2012); Tapia et al.,
(2010). According to Ko \& Liu (2016), research and development (R\&D) competence refers to a company's ability to create new competencies in exploring new technology. This relates to the company's ability to recover lost revenue due to discontinued products. Companies will tend to be motivated to develop research and development $(R \& D)$ competencies, which enable them to build new technological competencies. Ownership of these competencies often enables companies to identify and integrate new green-based technologies for their product development and develop environmentally friendly products to replace discontinued products. To be able to have dynamic capabilities a company needs to have three capabilities, namely adaptive capability, absorptive capability, and innovative capability (Tseng \& Lee, 2014). Digital technology has had a significant impact on economies around the world. More and more businesses are realizing the benefits of digital capabilities. Many consumers who are part of society are starting to become familiar with using technology in various activities. When companies have sufficient digital skills, businesses can build relationships with consumers much more intensely. Consumers become more and more and ultimately increase in income (Feerrar, 2019). Product innovation requires company investment in research and development activities (Gupta et al., 2016; Qurtubi et al., 2019).

\section{References}

[1] Adam-Turner, N., Burnett, D., \& Dickinson, G. (2020). A Study on Digital Literacy Perspectives when Designing Library Learning for Rural Community Colleges in the Connected Age. Designing Effective Library Learning Spaces in Higher Education, 75-99. doi:10.1108/s2055-364120200000029007

[2] Ajibroto, K., De Keizer, H., \& Pringgabayu, D. (2018). Analisis Lingkungan Strategis Untuk Meningkatkan Kompetitifitas Produk Perbankan. JRMSI - Jurnal Riset Manajemen Sains Indonesia, 9(1), 56-71. https://doi.org/10.21009/jrmsi.009.1.04

[3] Amri, A. (2020). Dampak Covid-19 Terhadap UMKM di Indonesia. Jurnal Brand, 2(1), 147-153. https://www.academia.edu/42672824/Dampak_Covid19 Terhadap UMKM di Indonesia

[4] Arend, R. J. (2013). Social and Environmental Performance at SMEs: Considering Motivations, Capabilities, and Instrumentalism. Journal of Business Ethics, 125(4), 541-561. doi:10.1007/s10551-013-1934-5

[5] Barney, J. (1991). Firm Resources and Sustained Competitive Advantage. Journal of Management, 17(1), 99-120. doi:10.1177/014920639101700108

[6] Behrens, S. J. (1994). A Conceptual Analysis and Historical Overview of Information Literacy. College \& Research Libraries, 55(4), 309-322. doi:10.5860/crl 5504309

[7] Bekoglu, F. B., \& Onaylı, C. (2016). Strategic Approach in Social Media Marketing and a Study on Successful Facebook Cases. European Scientific Journal, ESJ, 12(7), 261. doi:10.19044/esj.2016.v12n7p261

[8] Borchardt, M., Pereira, G., Ferreira, A. R., Soares, M., Sousa, J., \& Battaglia, D. (2020). Leveraging frugal innovation in micro- and small enterprises at the base of the pyramid in Brazil: an analysis through the lens of dynamic capabilities. Journal of Entrepreneurship in Emerging Economies, ahead-ofprint(ahead-of-print). doi:10.1108/jeee-02-2020-0031

[9] Brammer, S., Hoejmose, S., \& Marchant, K. (2011). Environmental Management in SMEs in the UK: Practices, Pressures and Perceived Benefits. Business Strategy and the Environment, 21(7), 423-434. doi:10.1002/bse.717

[10] Constantinides, E. (2014). Foundations of Social Media Marketing. Procedia - Social and Behavioral Sciences, 148, 4057. doi:10.1016/j.sbspro.2014.07.016

[11] Danneels, E. (2012). Second-order competences and 
Schumpeterian rents. Strategic Entrepreneurship Journal, 6(1), 42-58. doi:10.1002/sej.1127

[12] Day, G. S., \& Schoemaker, P. J. H. (2016). Adapting to FastChanging Markets and Technologies. California Management Review, 58(4), 59-77. doi:10.1525/cmr.2016.58.4.59

[13] Denford, J. S. (2013). Building knowledge: developing a knowledge-based dynamic capabilities typology. Journal of Knowledge Management, 17(2), 175-194. doi:10.1108/13673271311315150

[14] Erlanitasari, Y., Rahmanto, A., \& Wijaya, M. (2020). Digital economic literacy micro, small and medium enterprises (SMES) go online. Informasi, 49(2), 145-156. doi:10.21831/informasi.v49i2.27827

[15] Essid, M., \& Berland, N. (2018). Adoption of environmental management tools: the dynamic capabilities contributions. Sustainability Accounting, Management and Policy Journal, 9(3), 229-252. doi:10.1108/sampj-09-2017-0099

[16] Faccin, K., Balestrin, A., Volkmer Martins, B., \& Bitencourt, C. C. (2019). Knowledge-based dynamic capabilities: a joint R\&D project in the French semiconductor industry. Journal of Knowledge Management, 23(3), 439-465. doi:10.1108/jkm-042018-0233

[17] Feerrar, J. (2019). Development of a framework for digital literacy. Reference Services Review, 47(2), 91-105. doi:10.1108/rsr-01-2019-0002

[18] Gibson, P. F., \& Smith, S. (2018). Digital literacies: preparing pupils and students for their information journey in the twenty-first century. Information and Learning Science, 119(12), 733-742. doi:10.1108/ils-07-2018-0059

[19] Gonzalez, R. V. D., \& Melo, T. M. (2019). Analyzing dynamic capability in teamwork. Journal of Knowledge Management, 23(6), 1196-1217. doi:10.1108/jkm-08-2018-0478

[20] Gupta, S., Malhotra, N. K., Czinkota, M., \& Foroudi, P. (2016). Marketing innovation: A consequence of competitiveness. Journal of Business Research, 69(12), 5671-5681. doi:10.1016/j.jbusres.2016.02.042

[21] Hamann, R., Smith, J., Tashman, P., \& Marshall, R. S. (2016). Why Do SMEs Go Green? An Analysis of Wine Firms in South Africa. Business \& Society, 56(1), 23-56. doi:10.1177/0007650315575106

[22] Hamdan, H. (2018). INDUSTRI 4.0: PENGARUH REVOLUSI INDUSTRI PADA KEWIRAUSAHAAN DEMI KEMANDIRIAN EKONOMI. JURNAL NUSANTARA APLIKASI MANAJEMEN BISNIS, 3(2), 1. doi:10.29407/nusamba.v3i2.12142

[23] Han, Y., \& Li, D. (2015). Effects of intellectual capital on innovative performance. Management Decision, 53(1), 40-56. doi:10.1108/md-08-2013-0411

[24] Hermawati, A., \& Gunawan, E. (2020). The implementation of dynamic capabilities for small and medium-sized enterprises in creating innovation. VINE Journal of Information and Knowledge Management Systems, 51(1), 92-108. doi:10.1108/vjikms-082019-0121

[25] Hunt, S. D. (1997). Competing through relationships: Grounding relationship marketing in resource-advantage theory. Journal of Marketing Management, 13(5), 431-445. doi:10.1080/0267257x.1997.9964484

[26] Ikpeze, C. H. (2018). Designing E-Books: Enhancing Prospective Teachers' Digital Literacy Skills. Literacy Research, Practice and Evaluation, 29-42. doi:10.1108/s2048-045820180000009003

[27] Irawan, D. (2020). Peningkatan Daya Saing Usaha Micro Kecil dan Menengah Melalui Jaringan Usaha. Coopetition: Jurnal IImiah Manajemen, X(2), 103-116.

[28] Larrán Jorge, M., Herrera Madueño, J., Martínez-Martínez, D., \& Lechuga Sancho, M. P. (2015). Competitiveness and environmental performance in Spanish small and medium enterprises: is there a direct link? Journal of Cleaner Production, 101, 26-37. doi:10.1016/j.jclepro.2015.04.016

[29] Khalil, S., \& Belitski, M. (2020). Dynamic capabilities for firm performance under the information technology governance framework. European Business Review, 32(2), 129-157. doi:10.1108/ebr-05-2018-0102

[30] Khan, K. U., Atlas, F., Ghani, U., Akhtar, S., \& Khan, F. (2020). Impact of intangible resources (dominant logic) on SMEs innovation performance, the mediating role of dynamic managerial capabilities: evidence from China. European Journal of Innovation Management, ahead-of-print(ahead-of-print). doi:10.1108/ejim-07-2020-0276

[31] Ko, W. W., \& Liu, G. (2016). Environmental Strategy and Competitive Advantage: The Role of Small- and Medium-Sized enterprises' Dynamic Capabilities. Business Strategy and the Environment, 26(5), 584-596. https://doi.org/10.1002/bse.1938

[32] Kosasi, S., Vedyanto, \& Yuliani, I. D. A. E. (2018). Improving organizational agility of micro, small, and medium enterprises through digital marketing strategy. Proceedings - 2017 2nd International Conferences on Information Technology, Information Systems and Electrical Engineering, ICITISEE 2017, 2018-Janua(February 2018), 68-72. https://doi.org/10.1109/ICITISEE.2017.8285561

[33] Cetindamar Kozanoglu, D., \& Abedin, B. (2020). Understanding the role of employees in digital transformation: conceptualization of digital literacy of employees as a multi-dimensional organizational affordance. Journal of Enterprise Information Management, ahead-of-print(ahead-of-print). doi:10.1108/jeim01-2020-0010

[34] Kristinawati, D., \& Tjakraatmadja, J. H. (2018). BAGAIMANA KAPABILITAS DINAMIS DAN MANAJEMEN PENGETAHUAN BERPENGARUH KEPADA KINERJA PERUSAHAAN?: SEBUAH BANGUNAN MODEL KONSEPTUAL. Matrik: Jurnal Manajemen, Strategi Bisnis Dan Kewirausahaan, 99. doi:10.24843/matrik:jmbk.2018.v12.i02.p02

[35] Lee, S. M., Kim, S. T., \& Choi, D. (2012). Green supply chain management and organizational performance. Industrial Management \& Data Systems, 112(8), 1148-1180. https://doi.org/10.1108/02635571211264609

[36] Manderino, M., \& Castek, J. (2020). Digital Literacies for Disciplinary Learning: Pedagogies Youth Deserve. What's Hot in Literacy: Exemplar Models of Effective Practice, 3-15. doi:10.1108/s2048-045820200000011003

[37] Mohamud, M., \& Sarpong, D. (2016). Dynamic capabilities: towards an organizing framework. Journal of Strategy and Management, 9(4), 511-526. doi:10.1108/jsma-11-2015-0088

[38] Mokhtar, N. F. (2015). Internet Marketing Adoption by Small Business Enterprises in Malaysia. International Journal of Business and Social Science, 6(1), 59-65.

[39] Morgan, R. M., \& Hunt, S. (1999). Relationship-Based Competitive Advantage. Journal of Business Research, 46(3), 281-290. doi:10.1016/s0148-2963(98)00035-6

[40] Covid-19, New Normal, dan Perencanaan Pembangunan di Indonesia. (2020). Jurnal Perencanaan Pembangunan: The Indonesian Journal of Development Planning, 4(2), 240-252. doi:10.36574/jpp.v4i2.118

[41] Nasution, R. (2017). Effect of the Development of Communication Information Technology on Local Cultural Existence - Pengaruh Perkembangan Teknologi Informasi Komunikasi Terhadap Eksistensi Budaya Lokal. Jurnal Penelitian Komunikasi Dan Opini Publik, 21(1), 123858.

[42] Nuhu, N. A., Baird, K., \& Appuhami, R. (2019). The impact of management control systems on organisational change and performance in the public sector. Journal of Accounting \& Organizational Change, 15(3), 473-495. doi:10.1108/jaoc-082018-0084

[43] Parida, V., Oghazi, P., \& Cedergren, S. (2016). A study of how ICT capabilities can influence dynamic capabilities. Journal of Enterprise Information Management, 29(2), 179-201. doi:10.1108/jeim-07-2012-0039

[44] Qurtubi, Q., Trisnaningtias, D. M., \& Yudhanata, M. F. (2019). Identifikasi Variabel yang Berpengaruh terhadap Kinerja Pemasaran dan Indikator Kinerja Pemasaran untuk Industri Hotel. Jurnal Sistem Dan Manajemen Industri, 3(1), 1. doi:10.30656/jsmi.v3i1.1432 


\section{GENERAL MANAGEMENT}

[45] Rashidirad, M., \& Salimian, H. (2020). SMEs' dynamic capabilities and value creation: the mediating role of competitive strategy. European Business Review, 32(4), 591-613. doi:10.1108/ebr-06-2019-0113

[46] Roach, D., Ryman, J., Jones, R., \& Ryman, H. (2018). Enhancing Innovativeness: The Role of Dynamic Marketing Capabilities. Canadian Journal of Administrative Sciences / Revue Canadienne Des Sciences de l'Administration, 35(4), 563-576. doi:10.1002/cjas.1473

[47] Röder, N. (2017). Exploring the Effect of Workarounds in Ambidextrous Organizations. I 17, 217.

[48] Rosita, R. (2020). PENGARUH PANDEMI COVID-19 TERHADAP UMKM DI INDONESIA. JURNAL LENTERA BISNIS, 9(2), 109. doi:10.34127/jrlab.v9i2.380

[49] Salsabila, F. (2019). Pengaruh Literasi Ekonomi Dan Literasi Digital Terhadap Perilaku Berwirausaha Sektor Kuliner Yang Terdaftar Pada Aplikasi Go Food Di Pasar Segar Kota Makassar. Http://Eprints.Unm.Ac.Id//dd/Eprint/14271.

[50] Schilke, O., Hu, S., \& Helfat, C. E. (2018). Quo Vadis, Dynamic Capabilities? A Content-Analytic Review of the Current State of Knowledge and Recommendations for Future Research. Academy of Management Annals, 12(1), 390-439. doi:10.5465/annals.2016.0014

[51] Suliswanto, M. S. W., \& Rofik, M. (2019). DIGITALIZATION OF MICRO, SMALL \& MEDIUM ENTERPRISES (MSMES) IN EAST JAVA, INDONESIA. Muhammadiyah International Journal of Economics and Business, 2(1), 34-43. doi:10.23917/mijeb.v2i1.9380
[52] Talafidaryani, M. (2020). A text mining-based review of the literature on dynamic capabilities perspective in information systems research. Management Research Review, 44(2), 236267. doi:10.1108/mrr-03-2020-0139

[53] Martín-Tapia, I., Aragón-Correa, J. A., \& Rueda-Manzanares, A. (2010). Environmental strategy and exports in medium, small and micro-enterprises. Journal of World Business, 45(3), 266-275. doi:10.1016/j.jwb.2009.09.009

[54] TEECE, D., \& PISANO, G. (1994). The Dynamic Capabilities of Firms: an Introduction. Industrial and Corporate Change, 3(3), 537-556. doi:10.1093/icc/3.3.537-a

[55] Tiago, M. T. P. M. B., \& Veríssimo, J. M. C. (2014). Digital marketing and social media: Why bother? Business Horizons, 57(6), 703-708. doi:10.1016/j.bushor.2014.07.002

[56] Tseng, S.-M., \& Lee, P.-S. (2014). The effect of knowledge management capability and dynamic capability on organizational performance. Journal of Enterprise Information Management, 27(2), 158-179. doi:10.1108/jeim-05-2012-0025

[57] Wang, Y.-S. (2016). Dynamic capabilities in fashion apparel industry: emergent conceptual framework. Baltic Journal of Management, 11(3), 286-309. doi:10.1108/bjm-02-2015-0051

[58] Xu, F., \& Wang, X. (2019). Transactional leadership and dynamic capabilities: the mediating effect of regulatory focus. Management Decision, 57(9), 2284-2306. doi:10.1108/md-112017-1151

[59] Yuniarto, P. R. (2015). Masalah Globalisasi di Indonesia : Antara Kepentingan, Kebijakan, dan Tantangan. Jurnal Kajian Wilayah, 5(1), 67-95. 